\title{
Prescribing practice and evaluation of appropriateness of enteral nutrition in a university teaching hospital
}

This article was published in the following Dove Press journal:

Therapeutics and Clinical Risk Management

5 February 2013

Number of times this article has been viewed

\section{Xiu-Ping Zhu' \\ Ling-Ling Zhu ${ }^{2}$ \\ Quan Zhou'}

'Department of Pharmacy, ${ }^{2}$ Cadre Department, Division of Nursing, The Second Affiliated Hospital, School of Medicine, Zhejiang University, Hangzhou, Zhejiang Province, People's Republic of China
Correspondence: Quan Zhou Department of Pharmacy, The Second Affiliated Hospital, School of Medicine, Zhejiang University, Hangzhou, Zhejiang Province, People's Republic of China Tel +8657 I 87784615

Fax +86 57I 87022776

Email zhouquan142602@zju.edu.cn
Background: A retrospective utilization study was performed to evaluate utilization patterns for enteral nutrition in a university teaching hospital.

Methods: Enteral nutrition was divided into three types according to the nitrogen source, ie, total protein type [Nutrison Fibre ${ }^{\circledR}$, Fresubin Energy Fibre ${ }^{\circledR}$, Fresubin ${ }^{\circledR}$, Supportan ${ }^{\circledR}$ (a special immunonutrition for cancer patients or patients with increased demands for omega-3 fatty acids), Fresubin Diabetes ${ }^{\circledR}$ (a diabetes-specific formula), Ensure $\left.{ }^{\circledR}\right]$; short peptide type $\left(\right.$ Peptison $\left.^{\circledR}\right)$; and amino acid type $\left(V_{\text {Vivonex }}{ }^{\circledR}\right)$. A pharmacoeconomic analysis was done based on defined daily dose methodology.

Results: Among hospitalized patients taking enteral nutrition, 34.8\% received enteral nutrition alone, $30 \%$ concomitantly received parenteral nutrition, and $35.2 \%$ received enteral nutrition after parenteral nutrition. Combined use of the different formulas was observed in almost all hospitalized patients receiving enteral nutrition. In total, $61.5 \%$ of patients received triple therapy with Nutrison Fibre, Fresubin Diabetes, and Supportan. Number of defined daily doses (total dose consumed/ defined daily dose, also called DDDs) of formulas in descending order were as follows: Nutrison Fibre, Fresubin Energy Fibre, Fresubin Diabetes $>$ Supportan $>$ Peptison, Ensure $>$ Vivonex, Fresubin. The ratio of the cumulative DDDs for the three types of enteral nutrition was 35:2.8:1 (total protein type to short peptide type to amino acid type). Off-label use of Fresubin Diabetes was also observed, with most of this formula being prescribed for patients with stress hyperglycemia. Only $2.1 \%$ of cancer patients received Supportan. There were 35 cases of near misses in dispensing look-alike or sound-alike enteral nutrition formulas, and one adverse drug reaction in an elderly malnourished patient who did not receive vitamin K1-enriched enteral nutrition during treatment with cefoperazone. After 4 months of the trial intervention, off-label use of Fresubin Diabetes was no longer endorsed by the Drug and Therapeutics Committee for nondiabetic patients, and the proportion of this formula prescribed for patients with stress hyperglycemia decreased by $20 \%$, with a 10-fold increase in the amount of Supportan prescribed for cancer patients. Near misses in dispensing look-alike or sound-alike enteral nutrition were successfully abolished, and no severe coagulation disorders occurred after prophylactic administration of vitamin K1-enriched enteral nutrition in elderly malnourished patients receiving cefoperazone.

Conclusion: This utilization study indicates that continuous quality improvement is necessary and that a Drug and Therapeutics Committee can play an important role in promoting rational and safe use of enteral nutrition. Appropriateness of this therapy still needs to be improved, especially in addressing the issues of non-evidence-based combined use of multiple enteral nutrition formulas, the relatively high rate of concomitant use of enteral and parenteral nutrition, off-label use of diabetes-specific Fresubin Diabetes, insufficient use of Supportan in cancer patients, and unnecessary use of Supportan in intensive care patients not suffering from cancer.

Keywords: enteral nutrition, drug utilization, indications, parenteral nutrition, pharmacoeconomics, rational drug use 


\section{Introduction}

Compared with parenteral nutrition, enteral nutrition is less expensive and has fewer complications. If the gut works, enteral nutrition is preferred. ${ }^{1}$ Compared with parenteral nutrition, the cost savings associated with reduction in risk of adverse events and decrease in duration of hospital stay using enteral nutrition average nearly $\$ 4000$ per patient in the US. Shifting $10 \%$ of adult patients from enteral nutrition to parenteral nutrition will save $\$ 35$ million annually. ${ }^{2}$

Enteral nutrition formulas can be divided into three categories according to the nitrogen source, ie, total protein type, short peptide type, and amino acid type. Inappropriate ordering of enteral nutrition by physicians leads to unnecessary financial expense and decreased therapeutic efficacy, as well as an increased likelihood of adverse events. Therefore, it is necessary to be able to identify and monitor current prescribing patterns for enteral nutrition. However, no literature on enteral nutrition utilization patterns, especially the different types of enteral nutrition, was identifiable on the PubMed database. Therefore, we examined clinical risks and prescribing practices for enteral nutrition in hospitalized patients in a large university teaching hospital and investigated whether the three types of enteral nutrition were prescribed appropriately based on formula characteristics and patient disease status.

\section{Materials and methods Data collection}

This retrospective drug utilization study was performed in a tertiary university teaching hospital with 2200 beds. Data were obtained from the hospital information system and processed using Visual FoxPro version 9.0. Records of new or serious adverse events, and near misses associated with enteral nutrition, were audited retrospectively.

Eight enteral nutrition formulas were included: total protein type [Nutrison Fibre ${ }^{\circledR}$, Fresubin Energy Fibre ${ }^{\circledR}$, Fresubin ${ }^{\circledR}$, Supportan ${ }^{\circledR}$ (a special immunoenhancing formula for cancer patients or those with increased demands for omega-3 fatty acids), Fresubin Diabetes ${ }^{\circledR}$ (a diabetes-specific formula), Ensure ${ }^{\circledR}$; short peptide type (Peptison ${ }^{\circledR}$ ); and amino acid type $\left(V^{2}\right.$ ivonex $\left.{ }^{\circledR}\right)$. The nutritional components of these formulas are shown in Table 1.

\section{Statistical analysis}

A descriptive analysis was performed on all prescriptions of enteral nutrition for patients hospitalized in 2011. A defined daily dose (DDD) methodology was used. ${ }^{3}$ The defined daily doses for enteral nutrition were derived from package inserts and calculated based on the daily dose of nutritional supplements. Number of defined daily doses (also called DDDs) and daily expenditure were estimated using the following equations:

$$
\text { DDDs }=\text { Total dose consumed/DDD }
$$

Daily expenditure $=$ Overall expenditure/DDDs

Differences between patient groups were tested for statistical significance using the Student's $t$-test. A $P$ value $<0.05$ was considered to be statistically significant.

\section{Results \\ Combination use}

There were 2928 hospitalized patients taking enteral nutrition in 2011. Of these, 1020 (34.8\%) received enteral nutrition alone, 878 (30\%) patients received concomitant parenteral nutrition, and 1030 (35.2\%) received enteral nutrition following parenteral nutrition. The difference in age between patients receiving enteral nutrition alone and those receiving enteral and parenteral nutrition was not statistically significant $(P>0.05)$. The parenteral nutrition therapies were categorized according to energy and substitutes, ie, normal, high stress, and fluid-restricted. A team consisting of specialized doctors, nurses, clinical pharmacists, and dietitians assessed each patient's clinical status and decided on which parenteral nutrition formula to use. On average, 160 bags of parenteral nutrition mixtures were prescribed, most of which consisted of glucose, amino acids, lipids, water, electrolytes, essential vitamins, minerals, and trace elements. About 60 three-chamber bags of standard parenteral nutrition-based mixtures (Kabiven ${ }^{\circledR}$, Fresenius Kabi AB, Sweden) were used in intensive care units every day.

Combination use of multiple formulas was documented in $99.7 \%$ of hospitalized patients receiving enteral nutrition (Table 2). The relative percentage of different combination modes was as follows: triple therapy $(72.7 \%)>$ dual therapy $(24.8 \%)>$ quadruple therapy $(2.2 \%)$. The age difference between patients on monotherapy, dual therapy, triple therapy, and quadruple therapy with different enteral nutrition formulas was not statistically significant $(P>0.05)$. Surprisingly, $61.5 \%$ of patients on enteral nutrition received triple therapy of Nutrison Fibre, Fresubin Diabetes, and Supportan.

\section{Pharmacoeconomic data}

Pharmacoeconomic data for the eight enteral nutrition formulas are shown in Table 3. The values of DDDs in 
Table I Nutritional composition of eight enteral nutrition formulas

\begin{tabular}{|c|c|c|c|c|c|c|c|c|}
\hline & \multicolumn{8}{|c|}{ Type of enteral nutrition } \\
\hline & \multicolumn{6}{|c|}{ Total protein type } & \multirow{2}{*}{$\begin{array}{l}\begin{array}{l}\text { Short } \\
\text { peptide type }\end{array} \\
\text { Peptison }^{\circledR} \\
(500 \mathrm{~mL})\end{array}$} & \multirow{2}{*}{$\begin{array}{l}\text { Amino } \\
\text { acid type } \\
\text { Vivonex }^{\circledR} \\
(80.4 \text { g) }\end{array}$} \\
\hline & $\begin{array}{l}\text { Nutrison } \\
\text { Fibre }^{\circledR} \\
(500 \mathrm{~mL})\end{array}$ & $\begin{array}{l}\text { Fresubin } \\
\text { Energy Fibre }^{\circledR} \\
(500 \mathrm{~mL})\end{array}$ & $\begin{array}{l}\text { Fresubin }^{\circledR} \\
(500 \mathrm{~mL})\end{array}$ & $\begin{array}{l}\text { Supportan }^{\circledR} \\
(200 \mathrm{~mL})\end{array}$ & $\begin{array}{l}\text { Fresubin } \\
\text { Diabetes }^{\circledR} \\
(500 \mathrm{~mL})\end{array}$ & $\begin{array}{l}\text { Ensure }^{\circledR} \\
(400 \mathrm{~g})\end{array}$ & & \\
\hline $\begin{array}{l}\text { Energy density } \\
(\mathrm{kCal} / \mathrm{mL})\end{array}$ & 1.5 & 1.5 & 1.0 & 1.3 & 1.0 & $\begin{array}{l}1.0 \\
(55.8 \mathrm{~g} / 250 \mathrm{~mL})\end{array}$ & 1.0 & $\begin{array}{l}1.0 \\
(80.4 \mathrm{~g} / 300 \mathrm{~mL})\end{array}$ \\
\hline NPC:N & |33:| & 167:1 & $184: 1$ & |39:| & $165: 1$ & $174: 1$ & |72.4: | & $138: 1$ \\
\hline Pro:Fat:Car & $16: 35: 49$ & $15: 35: 50$ & $15: 30: 55$ & $18: 50: 32$ & $15: 32: 53$ & $14: 32: 54$ & 16:9:75 & $15: 3: 82$ \\
\hline Protein (g) & 30 & 28 & 19 & 11.7 & 17 & 63.6 & $\begin{array}{l}20 \text { (hydrolyzed } \\
\text { whey protein) }\end{array}$ & $\begin{array}{l}\text { I } 4.2 \text { (crystalline } \\
\text { amino acid) }\end{array}$ \\
\hline $\begin{array}{l}\text { Carbohydrates } \\
\text { (g) }\end{array}$ & 92.5 & 94 & 69 & 20.8 & 60 & 242.8 & 88 & 63 \\
\hline Lipids (g) & 29.5 & 29 & 17 & 14.4 & 16 & 63.6 & 8.5 & 0.51 \\
\hline Fiber $(g)$ & 7.5 & 10 & 0 & 2.6 & 7.5 & 0 & 0 & 0 \\
\hline $\begin{array}{l}\text { Omega-3 fatty } \\
\text { acids (g) }\end{array}$ & 1.53 & 0 & 0 & 0.6 & 0 & 0 & 0 & 0 \\
\hline $\begin{array}{l}\text { Osmolality } \\
(\mathrm{mOsm} / \mathrm{L})\end{array}$ & 300 & 320 & 250 & 330 & 320 & 320 & 470 & 610 \\
\hline
\end{tabular}

Abbreviations: NPC, nonprotein calorie to nitrogen ratio; Pro, protein; Car, carbohydrate.

descending order were: Nutrison Fibre, Fresubin Energy Fibre, and Fresubin Diabetes $>$ Supportan $>$ Peptison, and Ensure $>$ Vivonex and Fresubin. The ratio of cumulative DDDs for the three types of enteral nutrition was 35:2.8:1 (total protein type to short peptide type to amino acid type), and the order of daily expenditure was: Vivonex $>$ Peptison $>$ Supportan $>$ Fresubin Diabetes, Fresubin Energy Fibre, and Fresubin $>$ Ensure.

\section{Enteral nutrition according to ward type}

Nutrison Fibre and Fresubin Energy Fibre were prescribed more frequently in intensive care, burns, neurology, and neurosurgery wards than in other wards ( $80 \%$ versus $20 \%)$. Off-label use of Fresubin Diabetes was commonly observed. Of 331 patients receiving this formula, only four $(1.2 \%)$ patients suffered from diabetes. Most of this formula was prescribed for patients with potential stress hyperglycemia. The amount of Supportan consumed in oncology wards with 9600 person-time inpatients annually accounted for $6.9 \%$ of total consumption of this formula in this hospital.

Table 2 Combination use of different enteral nutrition formulas in hospitalized patients

\begin{tabular}{lll}
\hline Combination mode & $\mathbf{n}$ & Relative \% \\
\hline Total & 2928 & \\
Triple therapy & 2129 & 72.7 \\
Dual therapy & 726 & 24.8 \\
Quadruple therapy & 63 & 2.2 \\
Monotherapy & 9 & 0.3 \\
\hline
\end{tabular}

Only $2.1 \%$ of cancer patients received Supportan. Seven of the enteral nutrition formulas (ie, Nutrison Fibre, Fresubin Energy Fibre, Supportan, Fresubin Diabetes, Ensure, Peptison, and Vivonex) were prescribed more frequently in intensive care wards than in non-intensive care wards. Consumption in intensive care as a proportion of total consumption in all wards was: $57.0 \%$ (Nutrison Fibre), 47.5\% (Fresubin Energy Fibre), 37.9\% (Supportan), 53.5\% (Fresubin Diabetes), 20.7\% (Ensure), 54.9\% (Peptison), and $74.7 \%$ (Vivonex).

The top seven wards using the enteral nutrition formulas, based on cumulative DDDs, were intensive care, geriatrics, burns, neurology, neurosurgery, general surgery, thoracic surgery, and oncology. Cumulative DDDs of all enteral nutrition formulas in intensive care accounted for $48.7 \%$ of the sum of DDDs for all enteral nutrition formulas in this hospital. Relative percentages for the other six wards were: geriatrics $(11.3 \%)$, burns $(10.5 \%)$, neurology and neurosurgery $(9.7 \%)$, general surgery $(6.0 \%)$, thoracic surgery $(2.5 \%)$, and oncology $(2.0 \%)$.

\section{Near misses and adverse events}

In 2011, there were 35 cases of near misses when dispensing look-alike or sound-alike formulas of enteral nutrition. Fortunately, all these near misses made by pharmacists were detected and reported by clinical nurses.

Except for mild diarrhea, new or serious adverse events attributable to enteral nutrition were not detected 
Table 3 Pharmacoeconomic indices of eight enteral nutrition formulas for hospitalized patients

\begin{tabular}{llllll}
\hline Type & Drug name & DDD & DDDs & $\begin{array}{l}\text { Total expenditure } \\
\text { (CNY) }\end{array}$ & $\begin{array}{l}\text { Daily expenditure } \\
\text { (CNY) }\end{array}$ \\
\hline TP & Nutrison Fibre $^{\circledR}$ & $1333 \mathrm{~mL}$ & 9078 & $1,929,000$ & 212.5 \\
TP & Fresubin Energy Fibre $^{\circledR}$ & $500 \mathrm{~mL}$ & 8874 & 675,000 & 76.1 \\
TP & Fresubin Diabetes $^{\circledR}$ & $500 \mathrm{~mL}$ & 8839 & 819,000 & 92.6 \\
TP & Supportan $^{\circledR}$ & $1200 \mathrm{~mL}$ & 4970 & $1,714,000$ & 345 \\
TP & Ensure $^{\circledR}$ & $171 \mathrm{~g}$ & 2430 & 75,000 & 30.8 \\
TP & Fresubin $^{\circledR}$ & $1000 \mathrm{~mL}$ & 684 & 55,000 & 80.4 \\
SP & Peptison $^{\circledR}$ & $2000 \mathrm{~mL}$ & 2743 & $1,099,000$ & 400.9 \\
AA & Vivonex $^{\circledR}$ & $482.4 \mathrm{~g}$ & 992 & 442,000 & 445.6 \\
\hline
\end{tabular}

Abbreviations: DDD, defined daily dose; DDDs, total dose consumed/DDD; daily expenditure, overall expenditure/DDD; TP, total protein; SP, short peptide; AA, amino acid; CNY: Chinese Yuan Renminbi.

in 2011. However, there was one case of an adverse drug reaction in an elderly malnourished patient not receiving vitamin K1-enriched enteral nutrition during treatment with cefoperazone. This was a 98 -year-old bedridden tube-fed patient with an acute bacterial exacerbation of chronic bronchitis and cerebrovascular disease and suffering from a severe coagulation disorder induced by cefoperazone. A consultation was requested with a clinical pharmacist who identified that the cause of this adverse event was vitamin $\mathrm{K}$ deficiency caused by eradication of vitamin $\mathrm{K}$-producing intestinal bacteria or inhibition of action of vitamin $\mathrm{K} 1$ as a result of enteral nutrition given without vitamin $\mathrm{K}$ supplementation. The coagulopathy was corrected by administration of vitamin $\mathrm{K} 1$, cessation of the antibiotic, and addition of vitamin K-enriched high-density Nutrison Fibre $(20 \mu \mathrm{g} / 500 \mathrm{~mL})$. Prophylactic administration of vitamin $\mathrm{K} 1$ is now recommended for all elderly malnourished patients being treated with cefoperazone in this hospital.

\section{Preliminary intervention efforts}

The appropriateness of enteral nutrition attracted the attention of the Drug and Therapeutics Committee at our hospital in February 2012. A Plan-Do-Check-Act cycle was used for continuous quality improvement. ${ }^{4}$ After 4 months of this preliminary intervention, off-label use of Fresubin Diabetes was no longer approved by the Drug and Therapeutics Committee for nondiabetic patients, and the amount of this formula prescribed for patients with stress hyperglycemia decreased by $20 \%$. There was also a 10 -fold increase in the amount of Supportan prescribed for cancer patients. Near misses in dispensing of look-alike or sound-alike enteral nutrition were successfully abolished, and no cases of cefoperazone-induced severe coagulation disorder occurred when prophylactic vitamin K1-enriched enteral nutrition was administered to elderly malnourished patients receiving cefoperazone.

\section{Discussion}

\section{Combination of enteral and parenteral nutrition}

Clinical studies have shown that a combination of enteral and parenteral nutrition can improve the clinical outcome in intensive care patients, including reducing morbidity, length of stay, and recovery time, as well as improving quality of life and decreasing health care costs..$^{5-7} \mathrm{~A}$ meta-analysis has shown that $80 \%$ of critically ill patients can receive enteral nutrition alone, $10 \%$ can receive combined enteral and parenteral nutrition, and the remaining $10 \%$ need total parenteral nutrition. ${ }^{8}$ Our survey indicated that one-third of patients received combined enteral and parenteral nutrition. The relatively high rate of combination use of parenteral and enteral nutrition suggests that enteral nutrition alone may be inadequate.

No evidence for combined use of multiple enteral nutrition formulas is available in the PubMed database, so further investigations addressing this issue need to be performed. Triple therapy with one bottle each of Nutrison Fibre, Fresubin Diabetes, and Supportan costs about 600 Chinese Yuan Renminbi (CNY) per day and was considered to be overuse of medication, the underlying reasons for which are unclear. A pharmacoeconomic study on this issue needs to be performed in the future.

\section{Pharmacoeconomic indices}

The DDDs indicates trends in drug use, such that the higher DDDs of a therapy, the more frequent its utilization. In our study, the DDDs for Nutrison Fibre and Fresubin Energy Fibre ranked first and second, respectively, which may be due to the characteristics of the two formulas, ie, their 
high energy density $(1.5 \mathrm{kCal} / \mathrm{mL})$, high protein content (56-60 g/1000 mL), and amount of added dietary fiber (15-20 g/1000 mL). Peptison and Vivonex were found to have markedly lower DDDs compared with total protein type enteral nutrition, which may be attributed to the higher price and defined daily doses of these two formulas. The ratio of cumulative DDDs for the three types of enteral nutrition was 35:2.8:1 (total protein type to short peptide to amino acid type), reflecting formula characteristics. To our knowledge, ours is the first report of enteral nutrition consumption in clinical practice.

\section{Enteral nutrition consumption according to type of ward}

Table 4 summarizes the strengths and shortcomings of each of the eight enteral nutrition formulas investigated in this study. Nutrison Fibre and Fresubin Energy Fibre are concentrated formulas, and more suitable for patients who require water restriction because of brain injury or heart failure, as well as for patients with high energy and protein demands. Intensive care, burns, neurology, and neurosurgery wards accounted for about $80 \%$ of total consumption of Nutrison Fibre and Fresubin Energy Fibre. This utilization pattern may also reflect the characteristics of the two formulas.

Fresubin Diabetes is a diabetes-specific formula, as described in its package insert. It can reduce glucose load in patients with diabetes or glucose intolerance. Intensive care, geriatrics, and burns wards accounted for $80 \%$ of total consumption of Fresubin Diabetes. A literature review did not find evidence of off-label use of this formula (ie, for prevention of potential stress hyperglycemia). Although well controlled studies have demonstrated that hyperglycemia is an indicator of poor clinical outcome in inpatients, further studies are needed to determine whether Fresubin Diabetes helps to improve glycemic control.

Supportan is a high-fat, high-energy density, low carbohydrate formula which is designed based on the metabolic characteristics of tumor cells. (ie, a high glucose demand compared with benign cells of the same tissue) and is thus specific for cancer patients with malnutrition. ${ }^{9}$ It is also indicated for patients with an increased demand for omega-3 fatty acids. Our survey found that only $2.1 \%$ of cancer patients received Supportan, and the amount of this formula consumed in oncology wards accounted for only $6.9 \%$ of the total amount consumed in our hospital. Cumulative DDDs of all enteral nutrition formulas in oncology wards accounted for only $2 \%$ of the cumulative DDDs of the eight enteral nutrition formulas in all wards. The prescribing patterns for Supportan as well as other enteral nutrition formulas in the oncology wards indicated inadequate awareness of clinical nutrition support for cancer patients.

Consumption of Supportan in the intensive care setting accounted for $37.9 \%$ of total consumption by all wards, which may reflect the beneficial effects of omega-3 fatty acids in critically ill patients, ie, a reduced incidence of complications and shorter hospitalization times. ${ }^{10}$ However, more research is needed before definitive recommendations can be made concerning the routine use of omega-3 fatty acids in critically ill patients. ${ }^{11}$ Further, Nutrison Fibre contained a higher defined daily dose-based quantity of omega-3 fatty acids ( $4.1 \mathrm{~g}$ versus $3.6 \mathrm{~g})$ and was less expensive than Supportan (212.5 CNY versus $345 \mathrm{CNY}$, respectively). Therefore, routine use of Supportan in intensive care patients is not a cost-effective option, and doctors need to consider medication costs when prescribing for patients who do not have cancer.

Peptison is a peptide-based formula. Peptide-based enteral nutrition is easily used and more likely to improve nutritional status and immune function and thereby enhance postoperative recovery. The amount of Peptison consumed in intensive care and general surgery wards accounted for $54.9 \%$ and $17.7 \%$, respectively, of the total amount consumed. Again, the prescribing pattern for Peptison reflects its characteristics. From the perspective of pharmacoeconomics, a total proteinbased formula instead of a short peptide-based formula is the preferred choice for patients with normal or almost normal digestion and absorption in the gastrointestinal tract.

Vivonex is an amino acid-based formula and suitable for patients with severe metabolic disorders and gastrointestinal dysfunction. The amount of Vivonex consumed in intensive care accounted for $74.7 \%$ of the total amount consumed in the hospital, with the data yet again reflecting the characteristics of this formula.

Adequate nutritional support is important in the comprehensive management of patients in intensive care. Early administration of enteral nutrition maintains gastrointestinal integrity and function, thus minimizing the translocation of organisms, and reducing complication rates, length of stay in intensive care, and risk of death. American Society for Parenteral and Enteral Nutrition guidelines highlight enteral nutrition as the preferred route of feeding over parenteral nutrition in critically ill patients who require nutrition support, starting within the first 24-48 hours following admission to intensive care. ${ }^{12}$ The prescribing patterns 
Table 4 The strength and shortcomings of eight enteral nutrition formulas

\begin{tabular}{|c|c|c|c|}
\hline $\begin{array}{l}\text { Nitrogen } \\
\text { source }\end{array}$ & $\begin{array}{l}\text { Enteral } \\
\text { nutrition }\end{array}$ & Strength & Shortcomings \\
\hline \multirow[t]{6}{*}{$\begin{array}{l}\text { Total } \\
\text { protein }\end{array}$} & $\begin{array}{l}\text { Nutrison } \\
\text { Fibre }^{\circledR} \\
(500 \mathrm{~mL})\end{array}$ & $\begin{array}{l}\text { - It is more suitable for patients who need water restriction } \\
\text { and patients with high demand of energy and protein. } \\
\text { - It can be used for patients with diabetes mellitus. } \\
\text { - It can be used for patients over I year old. } \\
\text { - It contains more DDD-based quantity of omega-3 fatty } \\
\text { acid which may have beneficial effects in critically ill } \\
\text { patients than Supportan }{ }^{\circledR} \text {. }\end{array}$ & $\begin{array}{l}\text { - It is not suitable for patients requiring low } \\
\text { residue diet. } \\
\text { - Monitoring of fluid balance is required during } \\
\text { the course of treatment. }\end{array}$ \\
\hline & $\begin{array}{l}\text { Fresubin } \\
\text { Energy } \\
\text { Fibre }^{\circledR}(500 \mathrm{~mL})\end{array}$ & $\begin{array}{l}\text { - It is more suitable for patients who need water restriction } \\
\text { and patients with high demand of energy and protein. } \\
\text { - The fiber-rich formula facilitates the maintenance } \\
\text { of intestinal structure and function, and thus it is suitable } \\
\text { for long-term application. }\end{array}$ & $\begin{array}{l}\text { - It is not suitable for patients requiring low } \\
\text { residue diet. } \\
\text { - Monitoring of fluid balance is required during } \\
\text { the course of treatment. } \\
\text { - It is only indicated for adult patients. }\end{array}$ \\
\hline & $\begin{array}{l}\text { Fresubin }^{\circledR} \\
(500 \mathrm{~mL})\end{array}$ & $\begin{array}{l}\text { - This product does not contain dietary fiber so that it } \\
\text { can be used for serious gastrointestinal stenosis patients, } \\
\text { patients with intestinal fistula and bowel preparation } \\
\text { before the colonoscopy. }\end{array}$ & $\begin{array}{l}\text { - It is not suitable for patients with high demand } \\
\text { of energy and protein. } \\
\text { - Long-term use of this product is only suitable } \\
\text { for patients who should not take dietary fiber. }\end{array}$ \\
\hline & $\begin{array}{l}\text { Ensure }^{\circledR} \\
(400 \mathrm{~g})\end{array}$ & $\begin{array}{l}\text { - It is the cheapest product with the lowest daily } \\
\text { expenditure among } 8 \text { formulas. } \\
\text { - It can be used for children over } 4 \text { years old besides adults. } \\
\text { - Due to powder characteristics it is convenient for storage. } \\
\text { Unlike other emulsions which can be kept up to } 24 \text { hours } \\
\text { in a refrigerator after opening, it can be stored at room } \\
\text { temperature for three weeks once it has been opened. } \\
\text { - It is low-residue formula. }\end{array}$ & \\
\hline & $\begin{array}{l}\text { Supportan } \\
(200 \mathrm{~mL})\end{array}$ & $\begin{array}{l}\text { - It is a special immunonutrition for cancer patients } \\
\text { or patients with increased demands for omega- } 3 \text { fatty acids. }\end{array}$ & $\begin{array}{l}\text { - Routine use of Supportan }{ }^{\circledR} \text { in ICU is not an } \\
\text { economic choice. } \\
\text { - It is only indicated for adult patients. } \\
\text { - It is disease-specific formula and thus there are } \\
\text { strict indications. }\end{array}$ \\
\hline & $\begin{array}{l}\text { Fresubin } \\
\text { Diabetes }^{\circledR} \\
(500 \mathrm{~mL})\end{array}$ & $\begin{array}{l}\text { - This diabetes specific formula can reduce glucose load } \\
\text { in patients with diabetes or glucose intolerance. } \\
\text { - It is rich in dietary fiber content and helps to maintain } \\
\text { the function of gastrointestinal tract. }\end{array}$ & $\begin{array}{l}\text { - It is disease-specific formula and thus there are } \\
\text { strict indications. }\end{array}$ \\
\hline $\begin{array}{l}\text { Short } \\
\text { peptide }\end{array}$ & $\begin{array}{l}\text { Peptison }^{\circledR} \\
(500 \mathrm{~mL})\end{array}$ & $\begin{array}{l}\text { - The peptides can be easily absorbed by enzyme } \\
\text { hydrolysis in intestinal brush border. } \\
\text { - It may decrease inflammation and increase antioxidant } \\
\text { defenses in elderly patients with ischemic stroke, compared to } \\
\text { casein containing formula (eg, Nutrison Fibre }{ }^{\circledast} \text { ). } \\
\text { - It can be indicated for diabetes. }\end{array}$ & $\begin{array}{l}\text { - Compared with total protein-based formula, } \\
\text { it is not economic for patients with normal or } \\
\text { almost normal gastrointestinal digestion and } \\
\text { absorption function. }\end{array}$ \\
\hline $\begin{array}{l}\text { Amino } \\
\text { acid }\end{array}$ & $\begin{array}{l}\text { Vivonex }{ }^{\circledR} \\
(80.4 \mathrm{~g})\end{array}$ & $\begin{array}{l}\text { - It is amino acid based formula which can be directly } \\
\text { absorbed via enteral mucosa. It is suitable for patients } \\
\text { with severe metabolic disorders and gastrointestinal } \\
\text { dysfunction. } \\
\text { - Due to powder characteristics it is convenient for storage. } \\
\text { - The formula has no residue. }\end{array}$ & $\begin{array}{l}\text { - It is the most expensive formula with the highest } \\
\text { daily expenditure. } \\
\text { - It has obviously higher osmolality and thus } \\
\text { theoretically higher occurrence of osmotic } \\
\text { diarrhea compared with total protein-based and } \\
\text { peptide-based formulas. } \\
\text { - It is not indicated in children below } 10 \text { years old. }\end{array}$ \\
\hline
\end{tabular}

in intensive care in our survey indicate adequate enteral nutrition support.

Lam et al concluded that, in burns patients, early enteral nutrition had better effects than total parenteral nutrition on immune and metabolic function and reduces the rates of complications and mortality. ${ }^{13}$ Cumulative DDDs of all enteral nutrition formulas in the burns ward accounted for
$10.5 \%$ of the sum of DDDs for all enteral nutrition formulas in all wards, reflecting good awareness of the need for enteral nutrition support in burns patients.

Malnutrition is common both before and after stroke, with dysphagia adding to nutritional risk. Further, malnutrition leads to prolonged length of hospital stay, reduced functional status, and poorer survival. Early enteral nutrition 
supplements can significantly improve nutritional intake in undernourished stroke patients. ${ }^{14}$ The sum of DDDs for the eight enteral nutrition formulas consumed in the neurology ward ranked fourth. An enteral formula containing hydrolyzed whey protein can decrease inflammation and increase antioxidant defense in elderly patients with ischemic stroke to a greater extent than a standard enteral formula containing casein as the protein source. Whey protein-based enteral nutrition is superior to casein-based enteral nutrition for patients with stroke. ${ }^{15}$ However, hydrolyzed whey proteinenriched Peptison was prescribed far less often than caseinenriched Nutrison Fibre at our hospital, with the ratio of the DDDs for these two formulas being 15:1 (casein versus hydrolyzed whey protein). The daily expenditure on Peptison was nearly twice that of Nutrison Fibre, which may explain the utilization patterns seen for the two formulas in stroke patients.

\section{Conclusion}

In this study, clinical enteral nutrition utilization patterns were evaluated in a university teaching hospital. Generally, clinicians had good awareness of the need for nutrition support, with adequate use in intensive care, geriatrics, burns, neurology, and neurosurgery wards, and an appropriate ratio for use of the three different types of enteral nutrition in line with formula characteristics. However, ongoing quality improvement is necessary, in particular to address issues such as non-evidence-based combination use of multiple enteral nutrition formulas, a relatively high rate of concomitant use of enteral and parenteral nutrition, off-label use of diabetesspecific Fresubin Diabetes, insufficient use of Supportan in cancer patients, and the costly use of Supportan in intensive care patients without cancer.

\section{Acknowledgments}

This research was supported by the Zhejiang Provincial Bureau of Education (Y201016850) and the Zhejiang Provincial Bureau of Health (2012KYA090). We thank
Ling-Cheng $\mathrm{Xu}$ for his excellent assistance with data collection.

\section{Disclosure}

The authors report no conflicts of interest in this work.

\section{References}

1. Ochoa JB. Enteral nutrition: the preferred therapy in all patients with a functional gastrointestinal tract. Curr Med Res Opin. 2011;27:1769-1770.

2. Cangelosi MJ, Auerbach HR, Cohen JT. A clinical and economic evaluation of enteral nutrition. Curr Med Res Opin. 2011;27:413-422.

3. Carter J. Small-scale study using the PDCA cycle. In: Gift R, Kinney C, editors. Today's Management Methods: A Guide for the Health Care Executive. New York, NY: Wiley, John and Sons Inc; 1996.

4. Barozzi N, Tett SE. Gastroprotective drugs in Australia: utilization patterns between 1997 and 2006 in relation to NSAID prescribing. Clin Ther. 2009;31:849-861.

5. Heidegger CP, Thibault R, Berger MM, Pichard C. Supplemental parenteral nutrition for intensive care patients: a logical combination with enteral nutrition. Rev Med Suisse. 2009;5:2486,2488-2491. French.

6. Thibault R, Pichard C. Nutrition and clinical outcome in intensive care patients. Curr Opin Clin Nutr Metab Care. 2010;13:177-183.

7. Thibault R, Pichard C. Parenteral nutrition in critical illness: can it safely improve outcomes? Crit Care Clin. 2010;26:467-480.

8. Gramlich L, Kichian K, Pinilla J, et al. Does enteral nutrition compared to parenteral nutrition result in better outcomes in critically ill adult patients? A systematic review of the literature. Nutrition. 2004;20: 843-848.

9. Klement RJ, Kämmerer U. Is there a role for carbohydrate restriction in the treatment and prevention of cancer? Nutr Metab (Lond). 2011;6:75

10. Munroe C, Frantz D, Martindale RG, McClave SA. The optimal lipid formulation in enteral feeding in critical illness: clinical update and review of the literature. Curr Gastroenterol Rep. 2011;13:368-375.

11. Gerlach AT, Murphy C. An update on nutrition support in the critically ill. J Pharm Pract. 2011;24:70-77.

12. Marik PE, Zaloga GP. Early enteral nutrition in acutely ill patients: a systematic review. Crit Care Med. 2001;29:2264-2270.

13. Lam NN, Tien NG, Khoa CM. Early enteral feeding for burned patients - an effective method which should be encouraged in developing countries. Burns. 2008;34:192-196.

14. Mo YH, Rhee J, Lee EK. Effects of nutrition support team services on outcomes in ICU patients. Yakugaku Zasshi. 2011;131:1827-1833.

15. de Aguilar-Nascimento JE, Prado Silveira BR, Dock-Nascimento DB. Early enteral nutrition with whey protein or casein in elderly patients with acute ischemic stroke: a double-blind randomized trial. Nutrition 2011;27:440-444.
Therapeutics and Clinical Risk Management

\section{Publish your work in this journal}

Therapeutics and Clinical Risk Management is an international, peerreviewed journal of clinical therapeutics and risk management, focusing on concise rapid reporting of clinical studies in all therapeutic areas, outcomes, safety, and programs for the effective, safe, and sustained use of medicines. This journal is indexed on PubMed Central, CAS,

\section{Dovepress}

EMBase, Scopus and the Elsevier Bibliographic databases. The manuscript management system is completely online and includes a very quick and fair peer-review system, which is all easy to use. Visit http://www.dovepress.com/testimonials.php to read real quotes from published authors. 